\title{
NONFINANCIAL PERFORMANCE EVALUATION AS SIGNIFICANT AREA OF STRATEGIC BUSINESS MANAGEMENT
}

\author{
Jana HORNUNGOVÁ ${ }^{1}$ \\ ${ }^{1}$ Department of Economics, Faculty of Business and Management, Brno University of Technology, \\ Kolejní 2906/4, Brno 612 00, Czech Republic \\ E-mail: ${ }^{1}$ hornungova@fbm.vutbr.cz
}

Received 22 July 2016; accepted 21 November 2016

\begin{abstract}
The main aim of this paper is to provide the answer to the questions: Which areas of the company play an important role in the evaluation of the performance? Which areas are considered to be important? Due to the fact that the business environment is constantly changing, changes also occur in the trends relating to performance. Traditional financial performance measures have been highly criticized and the need identified to integrate non-financial perspectives, such as the level of innovation, degree of motivation, intellectual capital, and other criteria. Intellectual capital is often a crucial factor in the creation of value in a company. Based on the research, employees and customers are one of the most important areas in the companies from the selected area. At the same time, dependence among these company's areas and company's profit has been identified. Furthermore, it has been found whether the introduction of social responsibility into business strategy affects responsible behaviour just in the working environment (as this is geared specifically to employment area). Thus, as regards business strategy and support to work environment, in this case no relationship has been indicated, therefore it is not possible to say that if companies apply social responsibility strategy, they support mainly the working environment.
\end{abstract}

Keywords: performance, business management, competitiveness, intellectual capital; information and communication activities.

JEL Classification: L21, L25, M21.

\section{Introduction}

Corporate performance - a concept that very often occurs in the context of various analyses of the enterprise. Why do we hear so often about performance? The performance of the economy indicates the ability of the drive to achieve specific results, comparable on the basis of certain criteria, with the results of other units. In addition, the performance is considered to be the ability to achieve such results after a certain period of time. One of the fundamental problems of the company performance is how to measure the performance, as for different target groups around the company the performance has a different meaning. For this reason, the relevant procedures have been developed as well as the methods measuring the individual ratios and relationships (Kislingerová 2009, Milichovský 2015). Other authors have reported that the performance management is a continuous process of identifying, measuring, and developing individuals or teams, and of aligning that performance with the strategic goals of an organization (Aguinis 2009, Cascio and Aguinis 2011). Currently, there is a lot of competition in most sectors and businesses are in more and more difficult situation to resist the pressures of these competitors. It is, therefore, necessary to devote more effort to the search for options how to collect better information about customer needs, how to increase the efficiency of business processes and improve their situation.

Measuring and managing business performance is a relatively complex and difficult process. It is possible to undergoing significant changes both in practice and in research. Despite the ongoing effort to improve the methodology used, it seems that the traditional business performance management based primarily on financial management has

Copyright $\odot 2017$ The Authors. Published by VGTU Press.

This is an open-access article distributed under the terms of the Creative Commons Attribution-NonCommercial 4.0 (CC BY-NC 4.0) license, which permits unrestricted use, distribution, and reproduction in any medium, provided the original author and source are credited. The material cannot be used for commercial purposes.

To link to this article: https://doi.org/10.3846/btp.2017.008 
reached its limits and in recent years we have seen the development of new non-traditional indicators, methods and models based primarily on non-financial methods, in particular on strategic and other qualitative indicators. The current dynamic business environment makes it essential to understand the importance of one of the company's most valuable and volatile intangible assets - it is knowledge. Knowledge is sometimes considered a fifth factor of production in the current economy and its generation plays a critical role in the firm's competitive advantage and its economic performance. Organizations attempt to use knowledge in order to strengthen their competitiveness for both customers and employees (Singh and Samalia 2014, Rajnoha et al. 2016).

The results of this empirical scientific paper provides interesting and valuable findings that the overall performance of companies from Information and Communication Activities in Czech Republic is to be looked at comprehensively strategically and not just in financial terms. Which areas are important for evaluation of performance in selected area? Are socially responsible companies behave responsibly to their employees also in the area of working environment? The answers to these questions can be found in the paper.

\section{Theoretical background}

\subsection{Corporate performance}

Over the time, the performance has been measured either by the company size or its productivity and profit - so called financial corporate performance. The scientific literature divides financial indicators of the company performance into three categories:

- Accounting results and derivative indicators - the accounting result is the result from the financial statement. The basic indicator, which can be explained by means of the structural analysis of the profit and loss statement. Accounting indicators express the company's performance in absolute values. The application of these indicators is recommended for various comparisons: proportion of personal costs to turnover; productivity rate; proportion of business margin to turnover, etc. These indicators provide a clear picture of productivity (Brignall 2007).

- Traditional production indicators (indicators of financial productivity) - these indicators provide information through the value of invested assets. The best known indicator is ROI (return on investment), calculated as the ratio of the economic result to the cost of investment. Another traditional productivity indicator is the ratio of the net economic results to the equity capital ( $\mathrm{ROE}=$ return on equity). Ratio indicators of financial productivity provide information helping the company to compare its productivity, expected by shareholders, i.e., to evaluate so-called financial attractiveness.

- New category of financial indicators - represented by the metrics EVA (Economic Value Added); its positive value indicates that from purely financial point of view the company has successfully generated value after the payment of all capital investments, in particular from capital shareholders (Nicu 2012).

Recently, performance evaluation methods have significantly changed. Performance evaluation can be defined as the ability of a company to boost investments, put into business activities, contributing to continuous selfimprovement and accomplishment of business objectives (Šulák and Vacík 2005). Performance evaluation is one of the tools helping the company management to decide how to do the business activity effectively (Arena et al. 2015). Performance is needed in some way to monitor and evaluate the while that made sense to her in the company to deal with. Performance can be selected using the appropriate tools to increase, mainly the creation and implementation of such a system performance measurement and management, which will be used in accordance with the vision and strategy of the company and will integrate different perspectives on performance (Gaiardelli et al.2007). It only depends on the enterprise itself, if only focus on one area (one indicator), or view the performance will take a comprehensive view. Dobbs and Koller (2005) point to the fact that the company is able to create a comprehensive performance assessment tool that measures to create value and thus can assess how well the company is on the overall. Such assessment is much better and more effective than the individual performance metrics. The reason is mainly the fact that only some of the indicators are directly measurable and the overall evaluation is necessary to take into account both metrics longand short-term performance (Paladino 2007, Kotane and Kuzmina-Merlino 2012).

Business performance is closely linked with its strategies. The strategy outlines long-term objectives of the company, progress of each strategic operation and utilization of company resources necessary to meet the defined objectives in such a way so as the particular strategy would be based not only on the needs of the company alone, but would also take into account changes in its resources and abilities and, at the same time, would adequately respond to the changes in the environment. The basic aim of each corporate strategy is to maintain and improve the performance of the company (Porter 1998, Dedouchová 2001, Morgan et al. 2002, Marr 2006, Boyd and Gessner 2013, Saunila 2016).

It is up to every company where to pay its attention within the framework of the performance improvement. Some companies focus on the economic results; the others prefer intangible assets, which also largely contribute to the development of the company. The point is that employees 
are often just a competitive advantage, thanks to which the enterprise is able to achieve its stated goals, i.e., achieving the profitability. An enterprise should realize that employees are very important as they create the added value.

A certain relation must exist between the performance and company staff; it is the only way how the company can accomplish its objectives. The American National Standard on performance management (American National Standards Institute 2012) states these three elements that are closely related to this issue:

- Goal setting - the process of establishing objectives to be achieved over a period of time;

- Performance review - the process of assessing progress towards goals;

- Performance improvement plans - the process of addressing a specific individual performance issue.

Goal setting helps to communicate expectations. Performance verification provides a feedback; performance improvement plans are supposed to help the employees to develop their knowledge, thus maximizing their potential. While a thorough treatment of performance management issues is beyond the scope of this article, it is important at least to comment on the feedback process (Bersin 2013).

Recently, researchers have begun to examine firm performance as a function of alternative managerial orientations such as an entrepreneurial orientation (Ross and Westgren 2009, Verhees et al. 2011), market orientation (Verhees and Meulenberg 2004, Johnson et al. 2009), and strategic choice (Hansson 2007). For a firm to achieve success in implementing orientations different from a production orientation, the manager must have a willingness to change and to question current business strategies (Michaels and Gow 2015).

Given this, it is necessary to take into account also other indicators, especially some social one, which also affect the performance of the company, i.e., the rate of staff turnover and the number of applications that the company receives when looking for new candidates. An employee, who does not feel from his employer a certain level of motivation, would look for another company where he or she would gain a greater appreciation for the work done (Milichovský and Koleňák 2014). The social area is one of the most important part of the business management and corporate performance.

\subsection{Relationship between corporate performance and stakeholder's area}

The relationship between corporate activities and stakeholders, employees and other interest groups are presented using the concept of Corporate Social Responsibility (CSR). A business that does not respect integration of socially responsible behaviour (they are not socially responsible) into their strategies, systems, and procedures, will probably remain behind the competition. In fact, since the beginning of the emergence of the concept of CSR both its supporters and opponents exist, who are presenting their belief in the correctness of their opinion. Many experts have begun to focus on the empirical impact of CSR on the economic and financial performance. However, it should be added that to this day no general scientific consensus on this issue has been achieved and the views of many groups of experts and scientists are quite different. One of the first studies with the impact of CSR on economic performance is the work of Milton Moskowitz from the year 1972. The author out of 67 companies selected the 14 best in terms of the level of CSR and calculated the average growth in value of their shares. The result was the average appreciation of 7.28\% while the Dow-Jones Industrial Average exhibited a value slightly lower. This result was considered to confirm the hypothesis that CSR had a positive impact on the economic performance of the company (Moskowitz 1972).

Heinz (1976) used the correlation analysis of ROE, ROA and margins and in this case he showed a positive correlation between CSR and ROE. Cochran and Wood (1984) used several financial indicators in their work, and their conclusion was that the strongest correlation existed between CSR and the age of corporate assets, i.e., the enterprises with legacy assets reached lower valuation in terms of social responsibility.

Regarding the relationship between CSR and CFP (corporate financial performances), several studies found that CSR impacted CFP positively (Bird 2007, Nicolau 2008). Inoue and Lee (2011) did not find any significant effect of CSR both on ROA and Tobin's $q$ across three different dimensions of CSR. In another recent empirical study, Barnett and Salomon (2006) examined 61 mutual funds applying social responsibility screens and found a curvilinear relationship between the social investment and financial performance. They further found that financial performance varied with the type of social screens; while community relations screening helped financial performance, labor and environmental relations did not, underlining the importance of considering that different kinds of socially responsible activities could have different results (Lee et al. 2013).

How it is mentioned before, business performance is closely linked with its strategies. Strategies, especially strategic management it is aimed at stakeholders. Some empirical studies conducted around the world in recent years have also confirmed the relationship between strategic planning and business performance (Rudd et al. 2008). According to such studies, we can conclude that strategic planning has a positive effect on the business performance of the firm, respective of the sector in which it operates (Andersen 2000).

Some authors conclude that strategic planning has the potential to have a positive effect on firm's performance in a highly unstable environment and strategic planning is thus an important added value for the company in terms of its higher performance (Brews and Purohit 2007). 
Other similar research from Czech Republic was interested in the relationship between management tools and techniques and organizational performance. The study indicates that there is a positive significant relationship between management tools and techniques utilization and organizational performance (Afonina 2015).

Based the results of research of companies from the selected economic industrial segments in Slovakia, which show above-average business performance, have a strong focus on the systematic management of its strategic performance by applying modern management concepts and methods. Authors report that the key tool in increasing the overall performance of the enterprise in the selected Slovak industries seems to be employing a system of strategic performance management of the firm, supported by a knowledge-based Business Intelligence Information System (Rajnoha et al. 2016).

\section{Materials and methods}

The aim of this article was achieved using the qualitative primary data type. Primary data were collected through questionnaires and interviews held with a competent staff of enterprises. The questionnaire, which was compiled within the primary research, was designed based on the information gathered through the analysis of literary sources and company reports (mostly annual reports).

The selection of suitable respondents was used from the Czech Statistical Office and database from the producer Bureau van Dijk (Amadeus). For the purposes of the author's research, businesses meeting the following two conditions were selected:

- Registered economic companies from section $J$ (CZ-NACE) - Information and Communication Activities in the Czech Republic;

- Enterprises with $>250$ employees.

A basic sample was made of 56 companies which received the questionnaire. In total, 32 out of 56 companies answered (effectiveness almost 57.14\%). In terms of identification, it can be significantly statistically evaluated which types of legal form predominated: joint-stock companies (43.8\%) and limited liability companies (56.3\%).

During the analysis of the data, these statistical methods were used:

- The arithmetic mean is a statistical quantity, which in a sense reflects the typical value that describes a set of several values. Mean dataset $\left\{x_{1}, x_{2}, \ldots, x_{n}\right\}$ is defined as:

$$
\bar{x}=\frac{1}{n}\left(x_{1}+x_{2}+\cdots+x_{n}\right)=\frac{1}{n} \sum_{i=1}^{n} x_{i} .
$$

It is a therefore a sum of all values divided by their number (Hendl 2012).
- Modus is the value of the variable, which is set in the most common, so it is a typical (most frequent) character value. Is a typical value of the reference file and destination file by requiring sorting permutations character.

- Median, which represents an intermediate value of a structured set and therefore its relevance close to the arithmetical average value, a value which divides a series of increasingly aligned results in two equally large halves (Hendl 2012).

- Variance and standard deviation are among the basic rate variability data that characterize the serenity units file. Show how the values are distributed file or how the individual character values are different. Both quantities refer to the arithmetic mean - it measures the dispersion around the average cost. Variance reflects variability in the distribution of a random set of values around the mean. Variance can be defined as the arithmetic average of the squared deviations of individual values observed variables $x_{i}$ from the average of the entire file. The calculation uses the following formula:

$$
s^{2}=\frac{1}{n-1} \sum_{i=1}^{n}\left(x_{i}-\bar{x}\right)^{2} .
$$

- The square root of the variance is called the standard deviation. The standard deviation expresses how values differ from the mean value. It tells us how much they differ from each other typical cases investigated in the file numbers. Achieves its amount lower values are a set of elements mostly similar to each other, the opposite case indicates mutual differences (Hendl 2012). Formula for calculating the standard deviation has the form:

$$
s=\sqrt{\frac{1}{n-1} \sum_{i=1}^{n}\left(x_{i}-\bar{x}\right)^{2}} .
$$

- Fisher's exact test was used to verify the statistical hypotheses. To use the $\chi^{2}$ test, it is necessary that the theoretical frequency $n_{i j}^{\prime}$ was greater than 5 . In the event that any frequency satisfies this condition, its performance can be achieved by combining several adjacent classes. It is necessary, therefore, to look a certain way similar groups, factually related together. In the case of low frequency and the impossibility of merging the rows or columns can be used Fisher's exact test (test the independence of two characters), which ranks among the nonparametric tests, working with data on the nominal scale and in its simplest form in two classes. Fisher's exact test is based on the assumption that the marginal rate is considered constant. In this case tests $\mathrm{H}_{0}: \pi_{11}=p 1+p+1$ to the two-sided or one-sided alternative hypothesis. For 
each variant frequency can calculate the probability that, given the marginal frequencies $n_{1}, n_{2}, n_{.1}, n_{.2}$ created a table with the frequencies $n_{11}, n_{12}, n_{21}, n_{22}$. So we get:

$$
P=\frac{n_{1} ! n_{2 !} ! n_{.1} ! n_{.2} !}{n ! n_{11} ! n_{12} ! n_{21} ! n_{22} !} .
$$

The minimum levels of significance, from which we reject $\mathrm{H}_{0}$, calculate for right-sided and double-sided alternative hypothesis as:

$$
\alpha^{\prime}=\sum A \cdot p
$$

where: $A$ is for:

- two-sided test - a set of tables, where $\mathrm{p}$ is less than or equal probabilities observed frequency;

- one-sided test - a set of tables with the same values as a p-sided test while $\mathrm{n} 11$ is either equal to the frequency observed, or in the same session as the findings to the theoretical frequency (Anděl 2011, Rezanková 2010).

All calculations in the paper were analysed using the statistical program IBM SPSS 20.

\section{Results and discussion}

\subsection{Descriptive statistics}

First of all, the importance of the individual areas of the company within the assessment and performance management has been evaluated. It is a matter in which firms have scale-determine how the various areas are important to them or vice versa. The results are presented in Table 1.

The evaluation scale range was from 1 to 5 , wherein the value 1 was defined as the least important and 5 as the most important. On average, businesses identified as the most important in the evaluation of the performance the area of customer, employee and on the third position IS/IT. Customers are certainly important in the above strategies, thus in increasing sales and profits. Therefore, this area should not be neglected; the companies - correctly - assess this area as one of the most important ones. Furthermore, the staff is certainly another important area; many times, just the people create a competitive advantage and constitute the important component for sale.

The median, representing the mid-point value of the arranged file, i.e., its explanatory value is close to the arithmetic mean, reaches in all cases the values 4 and 5; despite the arrangement of the individual answers, these two weights have been the most frequently selected value for the individual areas.

Similar data also contains line mode that represents a value which is within the typical examined group. It is, therefore, the most frequent character value.

Then there are the basic characteristics of variability: variance and its root - standard deviation. Measures of variability characterize serenity units file, show how the values are distributed in the file or how the individual character values are different. The standard deviation expresses how values differ from the mean value. The standard deviation is rather low for all areas. I.e., it can be observed that all answers are very similar. The responses of respondents have deviated the least in the area of employment.

Maintaining the \% reliability of the test, the values for connection between individual areas and company profit have been determined within 0.05 , which represents $5 \%$ reliability level. Established values of $\alpha$ for the variables are: $\alpha$ Staff $=0.000 ; \alpha$ Customers $=0.000$ (i.e., less than 0.05). Therefore, that bring us to the conclusion that an alternative hypothesis is applied - there are dependencies between two individual areas and company profit.

Past results have revealed the relationship between company profit and company's areas. Subsequently, the degree of such dependence has been examined. To that end, the intensity of dependence determined by means of contingency coefficient as per formula (6) has been used.

$$
C_{p}=\sqrt{\frac{\chi_{n}^{2}}{\chi_{n}^{2}+n}},
$$

where: $C_{p}$ - contingency coefficient; $N$ - number of cases; $\frac{2}{p}$ - Pearson's chi-square.

$p$ The intensity of dependence ranges between $<0 ; 1>$. That means that the higher the absolute value, the greater the intensity of dependence. For the first connection (staff and

Table 1. Importance of the undertaking in the performance evaluation (source: own calculation)

\begin{tabular}{|l|c|c|c|c|c|c|c|}
\hline Variable & $F$ & $C$ & $I P$ & $S$ & $I$ & $S p l$ & $I S / I T$ \\
\hline Mean & 4.41 & 4.78 & 4.29 & 4.78 & 4.38 & 4.09 & 4.72 \\
\hline Median & 5.00 & 5.00 & 4.00 & 5.00 & 5.00 & 4.00 & 5.00 \\
\hline Modus & 5 & 5 & 4 & 5 & 5 & 4 & 5 \\
\hline$s$ & 0.712 & 0.553 & 0.643 & 0.420 & 0.793 & 0.689 & 0.581 \\
\hline$s^{2}$ & 0.507 & 0.305 & 0.413 & 0.176 & 0.629 & 0.475 & 0.338 \\
\hline
\end{tabular}

$F$ - finance; $C$ - customers; $I P$ - internal processes; $S$ - staff; $I$ - innovation; Spl - suppliers. 
company's profit) the value 0.772 has been calculated, i.e., the intensity inclines to be strong. For the second connection (customers and company's profit) the value 0.485 has been calculated, i.e., the intensity inclines to be medium.

\subsection{Statistical hypothesis}

While the company employees stand for one of the most important areas of the performance evaluation, the idea has been tested whether socially responsible companies behave responsibly to their employees also in the area of working environment. So the second part of this paper statistically evaluated the following statistical hypothesis that was established:

- Statistical hypothesis: "The introduction of responsible behaviour into the company strategy has an impact on the responsible behaviour in the area of the working environment".

It has been suggested that companies with the established responsible behaviour as the part of their strategy are responsible in the working environment. To test this hypothesis, respondents' answers from the questionnaire to these questions: "Is responsible conduct part of your corporate strategy?" and "In which of these areas are behaving responsibly CSR (working environment)?” were used. To verify the statistical correlation the null hypothesis $\mathrm{H}_{0}$ was tested that the random variables were independent versus the alternative hypothesis $\mathrm{H}_{1}$.

$-\mathrm{H}_{0}$ : there is no relationship between the established responsible behaviour in corporate strategy and responsible behaviour in the working environment.

$-\mathrm{H}_{1}$ : there is a relationship between the established responsible behaviour in corporate strategy and responsible behaviour in the working environment.

Fisher's exact test has been used to validate the hypothesis owing to the low frequency in the pivot table for two dichotomous variables and the impossibility to merge columns or lines (only answers "yes", "no"). The result of this test can be seen in Table 2. The output was obtained using IBM SPSS Statistics software.

The resultant value of the minimum level of significance was tested at $5 \%$ significance level $(\alpha=0.05)$. If the value is less than or equal to $\alpha=0.05, \mathrm{H}_{0}$ is rejected. Using the Fisher's exact test result, the $\mathrm{P}$-value $=0.088$ of the two-sided test was found-out. This value is higher than the selected level of significance $(0.088>0.05)$; therefore, in this case $\mathrm{H}_{0}$

Table 2. Fisher's exact test for the independence statistical hypothesis (source: own calculation)

\begin{tabular}{|l|c|}
\hline \multicolumn{1}{|c|}{ Variable } & $\begin{array}{c}\text { Two-sided alternative } \\
\text { hypothesis }\end{array}$ \\
\hline Fisher's exact test & 0.088 \\
\hline
\end{tabular}

at the $5 \%$ significance level is not rejected, while rejecting $\mathrm{H}_{1}$. Within the framework of this verification, we will leave $\mathrm{H}_{0}$ as no relationship between the responsible behaviour established in the strategy and responsible behaviour in the working environment has been demonstrated.

- The statistical hypothesis has not been confirmed.

I.e., with regard to the link between business strategy and support to working environment, no relationship has been proved in this particular case. Therefore, it is impossible to say that when the companies - within their strategies - operate with the social responsibility, they support particularly the working environment.

The author can undoubtedly say that disclosing value of the research could be increased if attended by more businesses. Nevertheless, the number of respondents was low enough that it is possible to evaluate the data and formulate certain conclusions. Among the main barriers to research it was a reluctance of businesses in obtaining primary data. If most of the data were publicly available, the research could be better; however, this is a general problem of voluntary reporting in the Czech Republic.

In the results of the paper there are characteristics of future research possibilities. The results of the paper can be used for compared with other industries or can be used for other type of companies, not only for large one.

\section{Conclusions}

The sector of Information and Communication Activities in Czech Republic is dominated by classic performance measurement systems (financial evaluation) and the simplicity and clarity of these approaches cannot be denied. Important in the management of business entities are objective values, as determined by the owners of the company, but the strategic success of the entity also increasingly affects its customers and employees. Integration of sustainability into the corporate strategies is very slow and rather limited to the introduction of voluntary instruments that are a condition of customers purchase. How mentioned Arena et al. (2015) performance evaluation is one of the tools helping the company management to decide how to do the business activity effectively. And corporate activity we can do with the people around the company (stakeholders). From the results of research by authors Rajnoha et al. (2016), traditional business management based on financial performance only must be confronted with the strategic performance management methods and concepts as soon as possible.

A content of this paper is to analyze the area of corporate performance. The main research issue of this study was to identify areas of the company that play an important role in the evaluation of the performance or are considered to be important. The research showed that in assessing the significance of the individual business areas for large 
companies from selected area (in the Czech Republic) the most important elements are employees and customers. In the third place IS/IT. For this purpose, the basic descriptive statistics was used. Furthermore, it has been surveyed whether the introduction of the social responsibility into the business strategy of the company influences responsible behavior in the area of working environment (as this area is prevailingly focused on the employment area). I.e., as to the business strategy and support to working environment, in this particular case (tested by the Fisher's exact test) no relationship has been proved. Thus, it is not possible to say that when the companies introduce the social responsibility into their strategies, they primarily support the working environment, i.e., their employees. Author's research conclusions comply with the statements of the authors Bird et al. (2007) and Nicolau (2008), where is a positive relationship between CSR and CFP (corporate financial performances). At the paper, dependence among the company's areas and company's profit has been identified. There were two important areas in relation to profit. For the first connection (staff and company's profit), the intensity inclines to be strong (0.772). For the second connection (customers and company's profit), the intensity inclines to be medium (0.485). Consequently, these areas are the most important from the point of dependence strength in relation to the company's profit.

Currently, the "firm's survival" depends not only on the financial competitiveness, equally important is that the organization could prove its status to various interested parties (stakeholders) that are affected by the activities of the enterprise. In other words, the fact those companies are facing increasing pressure from their environment to act in a socially responsible manner (Bučiūnienè and Kazlauskaitè 2012, Cardinaels and van Veen-Dirks 2010). Before the company shall decide for the key areas of corporate performance, it is important to understand how they can be best used and include them in the internal management. Following the results of research should companies be aware that satisfied and motivated employee who will have the required expertise, should be the goal of every company. The reason is that such employee is able to implement customer requirements in the required quality. Quality customer service helps to create a profile satisfied customer who is undertaking further source of company's revenue. Therefore, these areas should not be underestimated in the context of performance evaluation.

\section{Acknowledgements}

This paper is supported by The Czech Science Foundation. Name of the Project: Measuring Corporate Sustainability in Selected Sectors. Reg. No. 14-23079S.

\section{References}

Afonina A (2015) Strategic management tools and techniques and organizational performance: findings from the Czech Republic. Journal of Competitiveness 7 (3): 19-36. https:// doi.org/10.7441/joc.2015.03.02

Aguinis H (2009) Performance Management. Pearson Prentice Hall, New Jersey.

American National Standards Institute (2012) Performance Management Standard. VA: Society for Human Resource Management.

Anděl J (2011) Základy matematické statistiky. MatfyzPress, Prague.

Andersen TJ (2000) Strategic planning, autonomous actions and corporate performance. Long Range Planning 33 (2): 184-200. https://doi.org/10.1016/S0024-6301(00)00028-5

Arena M, Azzone G, Bengo I (2015) Performance measurement for social enterprises. Voluntas: International Journal of Voluntary and Nonprofit Organizations 26 (2): 649-672. https:// doi.org/10.1007/s11266-013-9436-8

Barnett ML, Salomon RM (2006) Beyond dichotomy: the curvilinear relationship between social responsibility and financial performance. Strategic of Management Journal 27 (11): 1101-1122. https://doi.org/10.1002/smj.557

Bersin J (2013) Predictions for 2014: Building a Strong Talent Pipeline for the Global Economic Recovery. Deloitte Development LLC, San Francisco: CA.

Bird R, Hall AD, Momente F, Reggiani F (2007) What corporate social responsibility activities are valued by the market? Journal of Business Ethics 76 (2): 189-206. https://doi.org/10.1007/ s10551-006-9268-1

Boyd N, Gessner B (2013) Human resource performance metrics: methods and processes that demonstrate you care. Cross Cultural Management 20 (2): 251-273. https://doi. org/10.1108/13527601311313508

Brews P, Purohit D (2007) Strategic planning in unstable environments. Long Range Planning 40 (1): 64-83. https://doi. org/10.1016/j.lrp.2006.12.001

Brignall TJS (2007) A financial perspective on performance management. Irish Accounting Review 14 (1): 15-29.

Bučiūnienè I, Kazlauskaitè R (2012) The linkage between HRM, CSR and performance outcomes. Baltic Journal of Management 7 (1): 5-24. https://doi.org/10.1108/17465261211195856

Cardinaels E, van Veen-Dirks PMG (2010) Financial versus nonfinancial information: the impact of information organization and presentation in a Balanced Scorecard. Accounting, Organizations and Society 35: 565-578. https://doi.org/10.1016/j. aos.2010.05.003

Cascio WF, Aguinis H (2011) Applied Psychology in Human Resource Management. Prentice Hall, New Jersey.

Cochran PL, Wood RA (1984) Corporate social responsibility and financial performance. Academy of Management Journal 27 (1): 42-56. https://doi.org/10.2307/255956

Dedouchová M (2001) Strategie podniku. C. H. Beck, Prague.

Dobbs R, Koller T (2005) Measuring long-term performance. Mckinsey Quarterly, 16-27. 
Gaiardelli P, Saccani N, Songini L (2007) Performance measurement of the after-sales service network - evidence from the automotive industry. Computers in Industry 58 (7): 698-708. https://doi.org/10.1016/j.compind.2007.05.008

Hansson H (2007) Strategy factors as drivers and restraints on dairy farm performance: evidence from Sweden. Agricultural Systems 94 (3): 726-737. https://doi.org/10.1016/j. agsy.2007.03.002

Heinz DC (1976) Financial correlates of a social measure. Akron Business and Economic Review 7 (1): 48-51.

Hendl J (2012) Přehled statistických metod: analýza a metaanalýza dat. Portál, Prague.

Inoue Y, Lee S (2011) Effects of different dimensions of corporate social responsibility on corporate financial performance in tourism-related industries. Tourism Management 32 (4): 790-804. https://doi.org/10.1016/j.tourman.2010.06.019

Johnson AJ, Dibrell CC, Hansen E (2009) Market orientation, innovativeness, and performance of food companies. Journal of Agribusiness 27 (1/2): 85-106.

Kislingerová E (2009) Jak měřit výkonnost podniku v časech krize. Úspěch - produktivita a inovace v souvislostech 4(4) http://e-api.cz/page/69567.jak-merit-vykonnost-podniku-vcasech-krize/

Kotane I, Kuzmina-Merlino I (2012) Assessment of financial indicators for evaluation of business performance. European Integration Studies 6: 216-224. https://doi.org/10.5755/j01. eis.0.6.1554

Lee S, Singal M, Ho Kang K (2013) The corporate social responsibility-financial performance link in the U.S. restaurant industry: do economic conditions matter? International Journal of Hospitality Management 32: 2-10. https://doi. org/10.1016/j.ijhm.2012.03.007

Marr B (2006) Strategic Performance Management. Leveraging and Measuring Your Intangible Value Drivers. Elsevier Ltd.

Micheels ET, Gow HR (2015) The effect of market orientation on learning, innovativeness, and performance in primary agriculture. Canadian Journal of Agricultural Economics 63 (2): 209-233. https://doi.org/10.1111/cjag.12047

Milichovský F (2015) Effectiveness of marketing activities in engineering in Czech Republic. Business: Theory and Practice 16 (2): 205-211.

Milichovský F, Koleňák J (2014) Methodology for the selection of compensation trade tools in SMEs. Danube 5 (3): 213-224. https://doi.org/10.2478/danb-2014-0012

Morgan NA, Clark BH, Gooner RA (2002) Marketing productivity, marketing audits, and systems for marketing performance assessment: integrating multiple perspectives. Journal of
Business Research 55 (5): 363-375. https://doi.org/10.1016/ S0148-2963(00)00162-4

Moskowitz MR (1972) Choosing socially responsible stock. Business and Society Review 1: 71-75.

Nicolau JL (2008) Corporate social responsibility: worth-creating activities. Annals of Tourism Research 35 (4): 990-1006. https://doi.org/10.1016/j.annals.2008.09.003

Nicu IE (2012) Company performance measurement and reporting methods. Annals of the University of Oradea, Economic Science Series 1 (2): 700-707.

Paladino B (2007) Five Keys Principles of Corporate Performance. John Wiley \& Sons, New Jersey.

Porter ME (1998) Competitive Strategy: Techniques for Analyzing Industries and Competitors. Free Press, New York.

Rajnoha R, Štefko R, Merková M, Dobrovič J (2016) Business intelligence as a key information and knowledge tool for strategic business performance management. E+M Ekonomie a Management 19 (1): 183-203. https://doi.org/10.15240/ tul/001/2016-1-013

Řezanková H (2010) Analýza dat z dotazníkových šetření. Professional Publishing, Prague.

Ross RB, Westgren RE (2009) An agent-based model of entrepreneurial behavior in agri-food markets. Canadian Journal of Agricultural Economics 57 (4): 459-480. https://doi. org/10.1111/j.1744-7976.2009.01165.x

Rudd J, Greenley G, Beatson A, Lings I (2008) Strategic planning and performance: extending the debate. Journal of Business Research 61 (2): 99-108. https://doi.org/10.1016/j. jbusres.2007.06.014

Saunila M (2016) Performance measurement approach for innovation capability in SMEs. International Journal of Productivity and Performance Management 65 (2): 162-176. https:// doi.org/10.1108/IJPPM-08-2014-0123

Singh H, Samalia H (2014) A business intelligence perspective for churn management. Procedia - Social and Behavioral Sciences 109: 51-56. https://doi.org/10.1016/j.sbspro.2013.12.420

Šulák M, Vacík E (2005) Měření výkonnosti firem. Eupress, Prague.

Verhees FJHM, Kuipers A, Klopcic M (2011) Entrepreneurial proclivity and farm performance: the cases of Dutch and Slovenian farmers. The International Journal of Entrepreneurship and Innovation 12 (3): 169-177. https://doi.org/10.5367/ ijei.2011.0039

Verhees FJHM, Meulenberg MTG (2004) Market orientation, innovativeness, product innovation, and performance in small firms. Journal of Small Business Management 42 (2): 134-154.

Jana HORNUNGOVÁ. Assistant Professor at Brno University of Technology, Faculty of Business and Management, Department of Economics. Research interests: business economics, economic and social corporate performance. During her work at university she participated in several grant projects. She is author or co-author of many publications that are focused on the field of research interests. 